Int. Agrophys., $2020,34,33-41$
doi: $10.31545 /$ intagr/116394

Review

\title{
Fish pond sediment from aquaculture production - current practices and the potential for nutrient recovery**: a Review
}

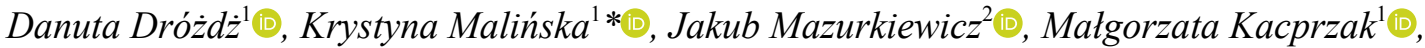 \\ Maciej Mrowiec $^{1}\left(\mathbb{0}\right.$, Agnieszka Szczypiór $^{1}{ }^{(0)}$, Przemystaw Postawa ${ }^{3}$, and Tomasz Stachowiak ${ }^{3}$

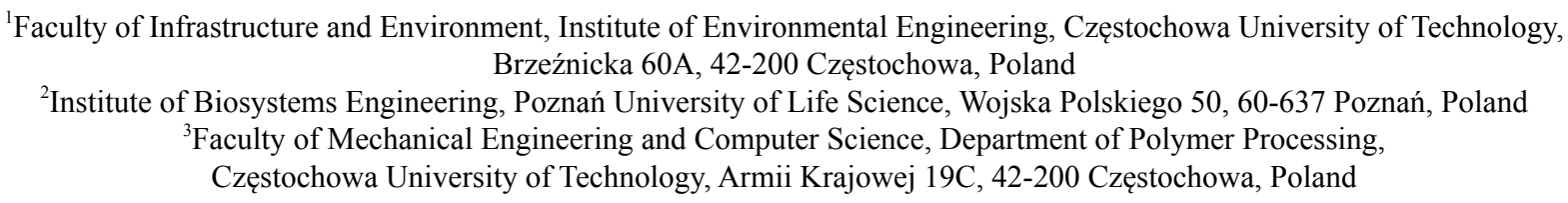

Received September 23, 2018; accepted July 24, 2019

Abstract. The recent increase in fish production has resulted in the accumulation of fish pond sediment. This sediment accumulates over time and can lead to a reduction in the depth of ponds and in the living space available for fish, it may also lead to a depletion in dissolved oxygen. Therefore, the removal of sediment from fresh water ponds is crucial for pond maintenance, and thus economical fish production. Fish pond sediment is rich in nutrients and organic matter, and therefore it may have potential as a fertilizer in crop production, nursery pot culture, etc. However, it contains compounds that undergo rapid degradation producing unpleasant odours and posing a threat to the environment, therefore it needs to be managed and handled efficiently in an environmentally sound and sustainable manner. The overall goal of this study was to analyse the current state and management practices of fish pond sediment generated in the existing aquaculture systems, with special reference to organic aquaculture, and the potential for the recovery of nutrients through bioconversion processes to organic fertilizers.

Keyw ords: fish pond sediment, intensive aquaculture, nutrient recovery, agriculture

\section{INTRODUCTION}

Over the last 40 years, there has been a gradual increase in the global production of fish from aquaculture estimated at an average annual rate of $8.8 \%$ (Haque et al., 2016). Many experts agree that the most significant increase in the consumption of fish is due to higher population, income

\footnotetext{
*Corresponding author e-mail: krystyna.malinska@pcz.pl

**This work was performed within the project on "Pathways to phase-out contentious inputs from organic agriculture in Europe (Organic PLUS)". This project has received funding from the European Union's Horizon 2020 research and innovation programme under grant agreement No. 774340 (2018-2020).
}

and urbanization (Delgado et al., 2003; Chowdhury et al., 2010). Numerous reports and predictions point to the growth of aquaculture worldwide and that by 2030 it will exceed the quantity of captured fish (Tran et al., 2017).

Fish production results in the generation and accumulation of fish pond sediment in aquaculture systems over time. An excessive sediment load may lead to a reduction in the depth of ponds and in the living space available for fish, it may also lead to a depletion in dissolved oxygen and in the release of toxic gases such as $\mathrm{H}_{2} \mathrm{~S}$ and $\mathrm{NO}_{2}$ (Mizanur et al., 2004; Rahman and Yakupitiyage, 2006; Bosma and Verdegem, 2011; Kibria and Haque, 2018).This in turn may impair the efficiency of fish farming, and thus lower economic performance thereby discouraging fish farmers from engaging with the industry (Mizanur et al., 2004; Hossain et al., 2016). In practice, the removal of fish pond sediment involves land spreading for the most part, and as such may contribute to the degradation of the environment. Fish pond sediment contains compounds that undergo rapid degradation producing unpleasant odours and posing a threat to the environment. Improper handling and the disposal of fish pond sediment may lead to nitrate contamination of groundwater and the eutrophication of surface water (Mizanur et al., 2004). Recent studies have shown that aquaculture systems may be a significant source of methane $\left(\mathrm{CH}_{4}\right)$ and nitrous oxide $\left(\mathrm{N}_{2} \mathrm{O}\right)$, and thus contribute to global warming (Ma et al., 2018). Therefore, the removal of sediment from aquaculture systems is crucial for pond

(C) 2020 Institute of Agrophysics, Polish Academy of Sciences 
maintenance, and thus economical fish production. Fish pond sediment is rich in nutrients like nitrogen 1.08-7.03 g $\mathrm{kg}^{-1}$, carbon $18.3-92.3 \mathrm{~g} \mathrm{~kg}^{-1}$, phosphorus $0.22-2.07 \mathrm{~g} \mathrm{~kg}^{-1}$, magnesium $0.62-2.93 \mathrm{~g} \mathrm{~kg}^{-1}$, potassium $0.62-2.25 \mathrm{~g} \mathrm{~kg}^{-1}$. Although, the content of organic matter (humus) is 0.76-3.2 $\mathrm{t}$ $\mathrm{ha}^{-1}$, fish pond sediment has shown potential as a fertilizer in crop production, nursery pot culture, etc. (Eymontt et al., 2017). To date, there have been very few studies that report on the quantities, properties and management practices of fish pond sediment generated in the inland aquaculture system in contrast to periodic reports concerning the monitoring of the bottom sediment of rivers and lakes. Fish pond sediment needs to be managed and handled rapidly in an environmentally sound and sustainable manner. There is little known about the management practices of fish pond sediment from different aquaculture systems, both organic and conventional. In addition, the characteristics and properties of fish pond sediment have not been sufficiently investigated and described in the literature. What is more, both the experts and researchers have indicated that there is a need for in-depth analysis of fish pond sediment potential for the recovery of nutrients and their use in agricultural applications (Quant et al., 2006; Remiszewska-Skwarek and Quant, 2008).

The overall goal of this study was to review the current state and management of fish pond sediment generated in the existing fish farming system, with special emphasis on organic aquaculture, and to analyse the potential for the recovery of nutrients through bioconversion processes to organic fertilizers. The scope of this review covers: 1) an analysis of aquaculture production in the EU with special emphasis on organic aquaculture, 2) an overview of different aquaculture systems typical for fish farming, 3) the characteristics of fish pond sediment and common practices for the management of fish pond sediment, and also 4) the analysis of fish pond sediment for nutrient recovery, soil improvement and fertilization.

\section{AQUACULTURE PRODUCTION IN THE EU}

Aquaculture production in the EU was estimated at $19.7 \%$ of the total fish production in 2015 . This accounted for $1.3 \mathrm{mln} t$ of fish whereas world production from aquaculture reached 106 million $t$ in 2015. China is by far the largest producer, accounting for $58 \%$ of world production, which exceeds 61 million t. The second largest producer of aquaculture products is Indonesia, accounting for $15 \%$ of world production approaching 16 million t. According to recent data, EU aquaculture production in 2015 mainly consisted of mussels (493 $000 \mathrm{t}$ ), trout (189000 t) and salmon $(186000 \mathrm{t})$, seabass and seabream $(162000 \mathrm{t})$; oysters (93000 t) and carp (81 000 t) (EU Organic Aquaculture, EUFOMA, 2017).
Among the EU member states the highest total aquaculture production in 2015 was reported for Spain (289821 t), United Kingdom (206834 t) and France (206800 t). Also, substantially high total aquaculture production was observed in Italy (148763 t), Greece (106118 t) and Netherlands (62920 t). In Poland, the total aquaculture accounted for 36971 t (EU Organic Aquaculture, EUFOMA, 2017). Aquaculture production in 2015 for EU countries is presented in Fig. 1.

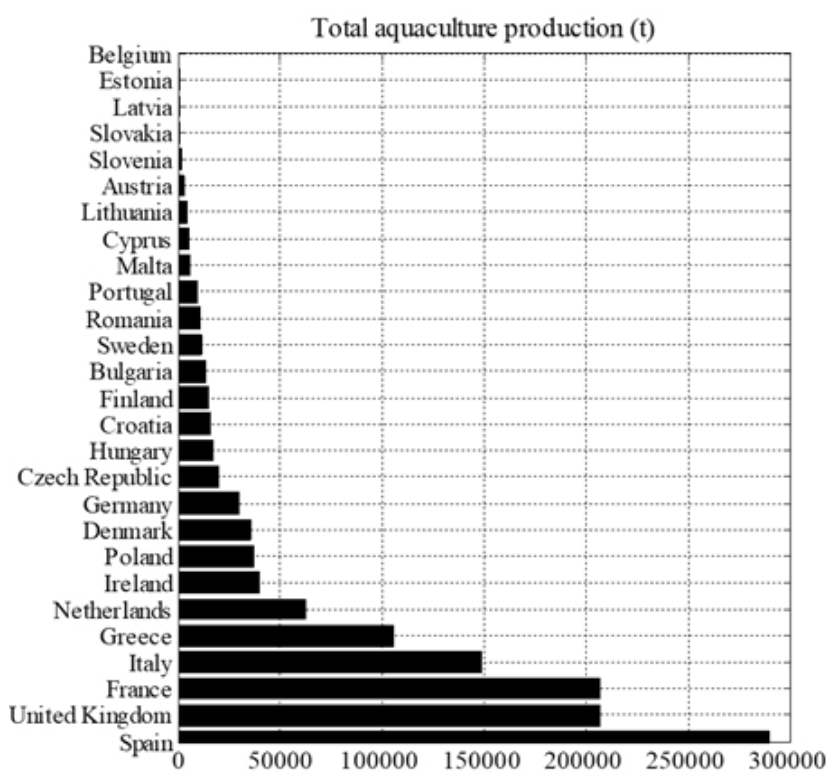

Fig. 1. Aquaculture production (tonnes) in the member states in 2015 (EU Organic Aquaculture, EUFOMA, 2017).

Total aquaculture production includes both conventional and organic production. In recent years, EU organic aquaculture has experienced significant growth. At the very least this has been observed for the major species: between 2012 and 2015 organic production increased by $24 \%$ for salmon, $25 \%$ for seabass/seabream, and it also doubled for rainbow trout, and positive developments have also been observed for shellfish (mussel, oyster). The share of organic aquaculture production among EU countries is presented in Fig. 2. The highest share of organic aquaculture in 2015 was reported for Ireland (55.5\%), Lithuania (25.1\%), Romania (24.7\%) and Hungary (20.2\%). In Poland, the share of organic aquaculture is estimated at $0.1 \%$ (EU Organic Aquaculture, EUFOMA, 2017).

\section{AQUACULTURE SYSTEMS}

Different fish farming systems are used in aquaculture production. They include extensive, semi-intensive and intensive flow systems and also breeding recirculating systems. Table 1 describes typical land-based fish farming systems. 
These systems generate different quantities of fish pond sediment, which may be handled and managed in different ways. For example, in organic flow-through systems the quantity of fish pond sediment is estimated at $8-10 \mathrm{~kg}$ (wet basis) from the production of 1 ton of fish (e.g. organic

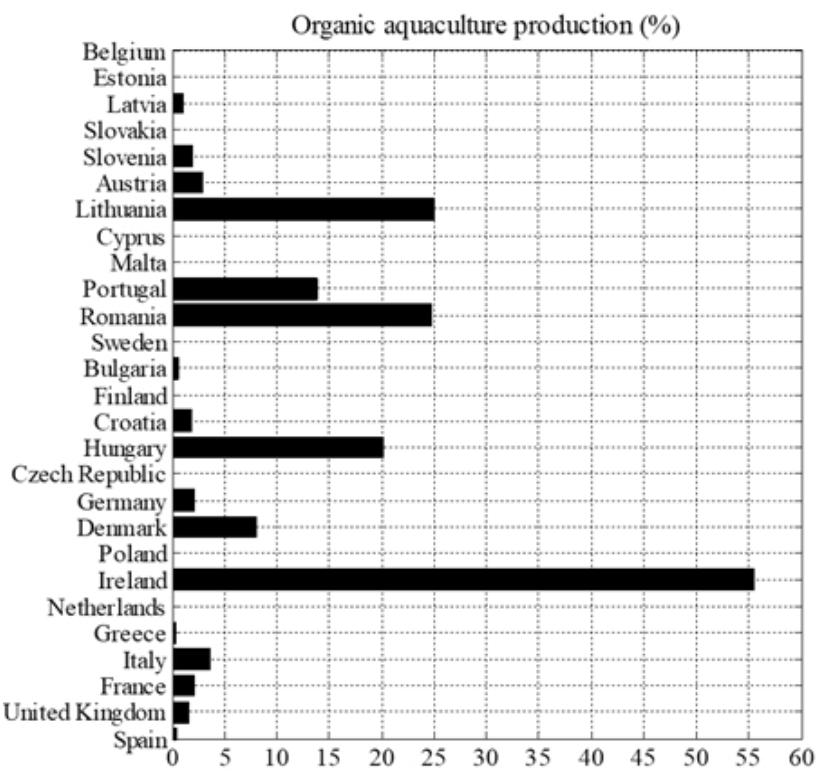

Fig. 2. Organic aquaculture production in member states in 2015 (EU Organic Aquaculture, EUFOMA, 2017). aquaculture of trout in Poland). The sediment is removed manually 2-3 times a year and stored on-site for drying or direct land application (personal communication with the owner of the organic rainbow trout farming in Złoty Potok, Poland, on July 1, 2018). In small fish ponds, a common practice for managing fish pond sediment is the mechanical removal of the sediment from the bottom of the pond usually after water is discharged from the pond, on-site storage frequently occurs on the ground surface and the sediment is covered with soil. Such practices for handling fish pond sediment may pose some threats to the environment. As for recirculating aquaculture systems (RAS) the quantity of fish pond sediment may be calculated using the nutritional approach from the apparent feed digestibility. For example, the aquaculture of rainbow trout in RAS generates from 148 to $338 \mathrm{~kg}$ of total solids per ton of fish (Van Rijn, 2013).

\section{MANAGEMENT OF FISH POND SEDIMENT}

Fish pond sediment constitutes a mixture of fish waste, decaying plant remains, dead algae, uneaten feed and faeces (Boyd et al., 2010; Muendo et al., 2014; MilhazaesCunha and Oter, 2017; Kokou and Fountoulaki, 2018), and as such they are rich in organic matter and nutrients. It is estimated that $10-30 \%$ of fish feed becomes faeces (Kokou and Fountoulaki, 2018). The sources of nutrients in ponds cover fish feed and both organic and inorganic fertilizers. The characteristics of fish pond sediment differ depending

Table 1. Characteristics of land-based fish farming systems (Centre for Sustainable Systems, University of Michigan, 2017)

\begin{tabular}{llll}
\hline & Aquaculture systems & & \\
\cline { 2 - 4 } Requirements & $\begin{array}{l}\text { Recirculating aquaculture } \\
\text { system (RAS) }\end{array}$ & Flow-through system (FTS) & Pond system \\
\hline
\end{tabular}

Water flow

Energy and water consumption

Infrastructure

Controlling the content of suspended solid and organic matter in water closed tanks

multiple water circulation in the water reservoir

high energy consumption low water consumption

constant control and filtration of water one-time water circulation in a water reservoir

high water consumption low energy consumption

tanks with water supplied from: river inflow, wells, pumped water from the nearby coast and outflow of water

difficult to control

places with water inflow not forced, natural water circulation

based on natural processes

ponds, ditches

using ecological processes to manage water quality
Location

most places (e.g. urban areas) place with natural water reservoirs 
on many factors including the type of aquaculture system (a recirculating aquaculture system, a flow-through aquaculture system, a pond system), the type and age of the fish, water quality, feeding type and regime, weather conditions, etc. Also, these factors can have an impact on the quantities of fish pond sediment generated during the aquaculture process and removed from the fish farming systems. The literature does not provide sufficient information concerning the quantities of fish pond sediment from various systems. However, it may be observed that greater quantities of fish pond sediment is generated in recirculating aquaculture systems than in other systems (Van Rijn, 2013). Selected physical and chemical properties of fish pond sediment investigated by other researchers are presented in Table 2 .

In most of the investigated types of fish pond sediment, the content of organic matter is relatively high. This is typical for intensive aquaculture systems. Also, fish pond sediment contains significant quantities of organic carbon, nitrogen, phosphorous and potassium. It is estimated that for semi-intensive aquaculture, about $80 \%$ of nitrogen and phosphorous is accumulated in fish pond sediment (Kibria and Haque, 2018). The values of $\mathrm{pH}$ differ depending on the origins of the fish pond sediment and can range from 4 to 8 . The $\mathrm{C} / \mathrm{N}$ ratio ranges from 13-16 (Eymontt et al., 2017).

Fish pond sediment also includes post-production pollutants, which usually accumulate in ditches and fisheries, during the dewatering of reservoirs, which takes place in order to catch fish. This period falls within the autumn season. Irregular cleaning of the bottom of reservoirs leads to difficulties in the flow of water in ponds. Also, it may lead to the accumulation of harmful and toxic substances in the water, and as a consequence, to the pollution of the surface waters (i.e. rivers, lakes) that are located in the close vicinity of the fish ponds (Eymontt et al., 2017).

Fish pond sediment intended for soil fertilization has to fulfil the requirements included in the relevant legal provisions. For example, according to the Polish Regulation of the Ministry of Rural Development of June 18, 2018, it is also important that fish pond sediment which is to be used for fertilizing purposes should not exceed the permissible values of pollutants, e.g. chromium $<100 \mathrm{mg} \mathrm{kg}^{-1} \mathrm{dry}$ matter, cadmium $<5 \mathrm{mg} \mathrm{kg}^{-1}$ dry matter, nickel $<60 \mathrm{mg} \mathrm{kg}^{-1}$ dry matter, lead $<140 \mathrm{mg} \mathrm{kg}^{-1}$ dry matter (Regulation of the Ministry of Rural Development, 2018).

According to Boyd and Massaut (1999) fish pond sediment from fish tanks can accumulate such substances as fertilizers, oxidants, coagulants, osmoregulators, pesticides, probiotics and heavy metals. They presented a list of substances that can be accumulated in bottom sediments. What is more, they also proposed a scale from 0 to 3 indicating the risk related to the danger of contamination to the environment and threats posed to human health and food. The risk of contamination with fertilizers is at $0-1$, which is very low. Substances such as sodium chloride and calcium sulphate are used to increase the salinity or lime content and to demonstrate the level of contamination risk of 0-1. Other substances such as algaecides and herbicides, copper compounds in the form of copper sulfate are moderately toxic to the aquatic environment and registered as 2 on the proposed scale. The risk associated with pesticides is at $0-1$, which is low. Significant pollutants that are bioaccumulative and can be carcinogenic to humans are heavy metals, arsenic, beryllium, cadmium, chromium, lead, manganese, mercury, silver, zinc. In this case, the risk was estimated at 3, which is high. Insecticides are also dangerous to the environment, humans and food as they can be easily bioaccumulated, and thus toxic - which corresponds to a risk level of 2-3. Water and soil can also be contaminated from the leakage of fuels and greases from machinery used in the vicinity of fish ponds. To prevent oil contamination it is necessary to seal leaking tanks, it is not advisable to store any fuels or other oily substances close to water reservoirs or plant crops (Boyd and Massaut, 1999).

Fish pond sediment might also pose a microbiological threat, especially when intended for soil fertilization, if it is not processed adequately (e.g. in composting). However, the literature provides very little information concerning this issue. Some microorganisms, for example Bacillius may be used as a probiotic, which positively influences the bottom sediment in fish tanks, increasing the decomposition of organic matter and reducing the nitrogen concentration (Boyd and Massaut, 1999). Also, fish pond sediment may contain pathogenic microorganisms due to the discharging and infiltration of poorly treated wastewater into the environment in the close vicinity of fish ponds (personal communication with the owner of the organic rainbow trout farming in Złoty Potok, Poland, on July 1, 2018)

Other threats that may be of importance to the application of fish pond sediment for soil fertilization include drugs or other substances for treating or supplementing fish. For example, according to Polish legislation a veterinarian is authorized to introduce veterinary medicinal products to the trade, which are admitted for the treatment of fish in Poland. The only drug that can be used is Ichtioxan (Active ingredients: Oxytetracycline hydrochloride, antibiotic). However, in extreme circumstances the veterinarian can prescribe medicine that is used in the EU, EFTA taking sole responsibility. This, if not properly executed - i.e. used in excessive quantities, may pose a threat to the environment and living organisms. An uncontrolled amount of therapeutics used in fish production causes the formation of bacterial strains that are resistant to antibiotics. It also has a toxic effect on fish, consumers and the aquatic environment. In order to prevent this, Polish restrictive regulations do not allow the use of certain medicinal products, which contain dimetronidazole, chloramphenicol, chloroform, chlorpromazine, colchicine, metronidazole, nitrofurans, ronidazole and malachite green. However, it should be pointed out that there have been relatively few studies conducted in Poland regarding medicines and their decomposition time in zoo- and phy- 
Table 2. Selected physical and chemical properties of fish pond sediment

\begin{tabular}{|c|c|c|c|c|c|c|c|c|}
\hline \multirow{3}{*}{$\begin{array}{l}\text { Type of fish pond } \\
\text { sediment }\end{array}$} & \multicolumn{7}{|c|}{ Parameters } & \multirow{3}{*}{ References } \\
\hline & $\mathrm{OM}$ & TOC & $\mathrm{TN}$ & \multirow{2}{*}{$\mathrm{C} / \mathrm{N}$} & \multirow{2}{*}{$\mathrm{pH}$} & $\mathrm{P}$ & $\mathrm{K}$ & \\
\hline & & $\mathrm{g} \mathrm{kg}^{-1}$ & & & & \multicolumn{2}{|c|}{$\mathrm{g} \mathrm{kg}^{-1}$} & \\
\hline $\begin{array}{l}\text { Sampled from the } \\
\text { RAS system (the } \\
\text { sample came from the } \\
\text { channel outlet from } \\
\text { the culturing units, fish } \\
\text { ponds) }\end{array}$ & 547.0 & 482.8 & 28.6 & 16.9 & 5.41 & 14.1 & 31.4 & $\begin{array}{l}\text { Kouba et al., } \\
2018\end{array}$ \\
\hline $\begin{array}{l}\text { Sampled from the } \\
\text { RAS system (from } \\
\text { immersed biofilters in } \\
\text { fish ponds) }\end{array}$ & 358.0 & 314.1 & 22.5 & 14.0 & 5.70 & 11.2 & 4.2 & $\begin{array}{l}\text { Kouba et al., } \\
2018\end{array}$ \\
\hline $\begin{array}{l}\text { Sludge was sampled } \\
\text { from the adjacent pond } \\
\text { which is used for } \\
\text { sedimentation of } \\
\text { effluent water }\end{array}$ & 179.0 & 160.0 & 11.7 & 13.7 & 6.31 & 11.1 & 4.9 & $\begin{array}{l}\text { Kouba et al., } \\
2018\end{array}$ \\
\hline $\begin{array}{l}\text { Sampled from inland } \\
\text { mixed-fish }\end{array}$ & - & $31.44 \pm 6.09$ & $1.59 \pm 0.09$ & - & 6.8 & - & - & Ma et al., 2018 \\
\hline $\begin{array}{l}\text { Sampled from organic } \\
\text { fish ponds }\end{array}$ & - & $24.05 \pm 2.76$ & $1.35 \pm 0.37$ & $18.85 \pm 7.28$ & 6.5 & $0.30 \pm 0.11$ & $0.69 \pm 0.09$ & $\begin{array}{l}\text { Eymontt et al., } \\
2017\end{array}$ \\
\hline $\begin{array}{l}\text { Sampled from } \\
\text { conventional fish } \\
\text { breeding }\end{array}$ & - & $34.6 \pm 2.69$ & $1.93 \pm 0.21$ & $18.10 \pm 3.39$ & 6.8 & $1.76 \pm 0.01$ & $0.82 \pm 0.09$ & $\begin{array}{l}\text { Eymontt et al., } \\
2017\end{array}$ \\
\hline $\begin{array}{l}\text { Sampled from } \\
\text { conventional fish } \\
\text { breeding }\end{array}$ & - & $37.5 \pm 27.15$ & $2.33 \pm 1.59$ & $15.80 \pm 0.85$ & 7.1 & $0.36 \pm 0.20$ & $1.39 \pm 0.61$ & $\begin{array}{l}\text { Eymontt et al., } \\
2017\end{array}$ \\
\hline $\begin{array}{l}\text { Sampled from } \\
\text { conventional fish } \\
\text { breeding }\end{array}$ & - & $89.7 \pm 3.68$ & $6.68 \pm 0.50$ & $13.45 \pm 0.49$ & 6.9 & $1.85 \pm 0.31$ & $2.09 \pm 0.23$ & $\begin{array}{l}\text { Eymontt et al., } \\
2017\end{array}$ \\
\hline $\begin{array}{l}\text { Fish pond sediment } \\
\text { contaminated with } \\
\text { agents used in } \\
\text { agriculture }\end{array}$ & - & - & 1.89 & - & 4.2 & 0.52 & 4.33 & Li et al., 2011 \\
\hline $\begin{array}{l}\text { Brackish aquaculture } \\
\text { sludge }\end{array}$ & - & $398 \pm 18$ & $47.4 \pm 3.4$ & $9.1 \pm 0.8$ & 7.31 & $11.1 \pm 1.2$ & - & $\begin{array}{l}\text { Mirzoyan et } \\
\text { al., } 2008\end{array}$ \\
\hline $\begin{array}{l}\text { Brackish aquaculture } \\
\text { sludge }\end{array}$ & - & $429 \pm 19$ & $38.7 \pm 4.0$ & $10.3 \pm 0.8$ & 7.0 & $19.1 \pm 4.1$ & - & $\begin{array}{l}\text { Mirzoyan et } \\
\text { al., } 2008\end{array}$ \\
\hline $\begin{array}{l}\text { Brackish aquaculture } \\
\text { sludge }\end{array}$ & - & $318 \pm 19$ & $35.8 \pm 2.7$ & $9.9 \pm 1.9$ & 7.7 & $30.8 \pm 3.0$ & - & $\begin{array}{l}\text { Mirzoyan et } \\
\text { al., } 2008\end{array}$ \\
\hline $\begin{array}{l}\text { Fish pond sediment } \\
\text { that may contain } \\
\text { impurities from } \\
\text { inorganic fertilizers }\end{array}$ & 29.0 & - & 2.14 & - & 6.0 & - & - & $\begin{array}{l}\text { Rahman and } \\
\text { Yakupitiya, } \\
2006\end{array}$ \\
\hline
\end{tabular}


toplankton or bottom sediments. There are also no specific statistical data concerning the impact of medicine on fish, consumers and the environment (Antychowicz et al., 2017).

In general, fish pond sediment and its properties may differ due to its origin, i.e. the system, which was used for aquaculture. This includes conventional as well as organic systems. However, there are very few references in the literature to organic fish pond sediment describing in detail issues related to the properties of fish pond sediment including the quantities generated or the ways of handling it. Table 3 presents the main differences in fish farming under organic and conventional conditions (The Code of Best Practices for Fish Breeding, 2015; Organic production of fish in the EU, 2016). These differences are presented for cyprinids and trout fish due to the fact that for the past several years, carp and rainbow trout have been predominant in the production of freshwater fish in Poland (Fish market and consumption, 2016).

Mainly due to the relatively high content of organic matter and nutrients, fish pond sediment demonstrates a high potential for agricultural and horticultural applications as a soil improver and a fertilizer (Mizanur et al., 2004; Rahman and Yakupitiyage, 2006; Haque et al., 2016). Rahman and Yakupitiyage (2006) studied the potential of fish pond sediment as a soil improver. They found that the application of $30 \%$ of sediment improved the soil aggregate stability and decreased the bulk density of the investigated farm soil to the required levels. Fish pond sediment can also be used as an ingredient in potting media. As it demonstrates a relatively high organic matter content, fish pond sediment can be mixed with sand and used in nurseries, green houses, etc. Also, it can be used as a substrate for mushroom culture (Mizanur et al., 2004). Haque et al. (2016) investigated pangasius pond sediment for agricultural use. Pangasius pond sediment showed high levels of organic carbon, nitrogen, phosphorus, potassium and sulphur and was used as a fertilizer for fodder grass production.

The composition of fish pond sediment indicates that this type of material is more of a resource rather than a waste (Mizanur et al., 2004; Rahman and Yakupitiyage, 2006). Therefore, there is an interest in fish pond sediment and its potential for nutrient recovery. There have already been a few studies conducted to investigate the potential of fish pond sediments for the recovery of nutrients through different biological processes into added value products that may be used for agricultural applications. Table 4 presents some recent examples of methods for managing fish pond sediment.

Some recent studies indicate that fish pond sediment can be managed through biological processes such as composting and vermicomposting to obtain compost and vermicomposts. Composting fish pond sediment requires the selection of the proper type and ratio of bulking agent in order to adjust the moisture content, $\mathrm{C} / \mathrm{N}$ ratio and air-filled porosity in the initial composting mixtures. The literature provides some examples of different types of agricultural residues such as rice and wheat straw, potato plant or mustard stover that were used in the composting of fish pond sediment (Karak et al., 2013). Zhang and Sun (2017) investigated the addition of air-dried fish pond sediment and rock phosphate for the composting of green waste. Recent studies have focused on analysing the potential of fish pond sediments for anaerobic digestion and the production of biogas (Parvathy et al., 2017).

The examples provided of different methods applied for managing and handling fish pond sediment and transforming it into a soil improver or a fertilizer indicate that recovering the nutrients and circulating them back to the environment could be feasible in fish farming. This could be accomplished by integrating aquaculture production with the on-site transformation of fish pond sediments through different biological processes. Kouba et al. (2018) suggested the application of on-site vermicomposting as it is considered to be a clean and sustainable method for converting fish pond sediment into vermicompost of high value for agricultural use. In addition, fish pond sediment with suitable amendments can be used as a growing media for earthworm biomass.

\section{SUMMARY}

Aquaculture production has been increasing worldwide over the past few decades. This trend has been observed for both conventional and organic fish farming. The gradually increasing production of fish from fish farms has resulted in higher quantities of fish pond sediment. Mainly due to the type of aquaculture system used, as well as the feeding composition and regime, the production of fish can generate substantial quantities of fish pond sediment. Fish pond sediment has to be removed periodically in order to maintain appropriate conditions for the growth of fish in the aquaculture system. Depending on many factors such as the type of aquaculture system used, water quality, fish type and age, feeding type and regime, the maintenance regime of fish tanks/ponds, etc., the composition and properties of fish pond sediments may vary significantly.

Fish pond sediment is rich in organic matter and nutrients. When managed improperly fish pond sediment can undergo rapid degradation resulting in the emission of odours and gases posing a potential threat to the environment. The available data indicates that fish pond sediment may contain a high content of organic matter, organic carbon and nitrogen, and also phosphorous and potassium. However, there is little known about the sanitary aspects of fish pond sediment as well as the presence of contaminants such as heavy metals or pharmaceuticals. Typical management practices for fish pond sediments include land spreading, direct agricultural applications and/or mixing with compost prior to agricultural applications. However, due to its composition there is a growing interest in other 
Table 3. Comparison of conventional and organic fish farming

\begin{tabular}{llll}
\hline Conditions & Organic fish pond & Conventional fish pond & References \\
\hline $\begin{array}{l}\text { Number of fish in } \\
\text { water tanks }\end{array}$ & *Example for cyprinids & *Example for cyprinids & Barszczewski et al., 2010 \\
Nourishment & Organic aquaculture feed products. & Cereal feed: barley, wheat, rye. & $\begin{array}{l}\text { Organic production of fish } \\
\text { in the EU - under a new }\end{array}$ \\
& & & $\begin{array}{l}\text { flag to the tables of the } \\
\text { world, 2016 }\end{array}$
\end{tabular}

Fishmeal and oils from organic aquaculture trimmings.

Ecological feed materials of plant and animal origin.

The use of astaxanthin for salmonids originating from ecological sources, e.g. from the crust of ecological crustaceans.

The presence of GMO products in feed, below $1 \%$ is allowed.

Preventive treatments

Treatment

Unit cost of fish

*Example for cyprinids

production

Preventive treatments:

Only Ichtioxan containing the active substance oxytetracycline hydrochloride is acceptable.
Prepared feed mixtures.

* Excessively high content of wheat in the feed leads to fish fattening

Sweet and bitter lupins.

Ground/roasted/post-extracted soya meal.

Granulated fodder, $<25 \%$ protein, greater amount of protein causes the problem with digestive system.

Conditioned and healing diets, administered under the control of ichthyopathologist.

Disinfection agents:

- formalin $35-37 \%$, 3-5\% solution, used for disinfecting shoes, concrete ponds,

- chloramine $\mathrm{T}, 30 \mathrm{~g} \mathrm{l}^{-1}$ of water, disinfection of tools, fishing nets, - calcium oxide, 75-400 $\mathrm{g} \mathrm{m}^{-3}$, lower doses for more sandy ponds, to the swampy bottom higher. It is only after about 6 weeks, when the $\mathrm{pH}$ is at 8.5 , it is recommended to stock the fish in the pond,

-Virkon, 1-2\% solution, concrete ponds, fishing equipment, disinfection mats. It can react with metal elements, - Rapicid, 1:100 - 1:600 solution, concrete ponds, disinfection mats, fishing equipment.

Ichtioxan containing the active

substance oxytetracycline hydrochloride.

However, if a given veterinary product is not available in Poland, in extreme cases veterinarians may, on their own responsibility, prescribe medications used in the treatment of other animals, humans or medicines authorized in EU and EFTA*

* Example for cyprinids 5-6 zł/kg (1.2-1.4 EURO)
Barszczewski et al., 2010

Prevention in pond breeding of fish, 2016

Antychowicz et al., 2017

Barszczewski et al., 2010

*EFTA- European Free Trade Association. 
Table 4. Methods for managing fish pond sediments

\begin{tabular}{|c|c|}
\hline Method & Description \\
\hline Soil application & $\begin{array}{l}\text { Fish pond sediment applied to soil as a } \mathrm{f} \\
\text { plants: Festuca rubra, Festuca arudinac } \\
\text { multiflorum, Lolium westerwoldicum. }\end{array}$ \\
\hline Soil application & $\begin{array}{l}\text { Pangasius pond sediment with urea used } \\
\text { grass production. }\end{array}$ \\
\hline Fish feeding & $\begin{array}{l}\text { Depending on the composition, fish pon } \\
\text { ingredient for fish feed. High risk of mic }\end{array}$ \\
\hline Construction & $\begin{array}{l}\text { Fish pond sediment used in construction } \\
\text { levees, road embankments, quays, miner } \\
\text { The requirements for the sediments incl } \\
\text { content, grain size, consistency, compact } \\
\text { parameters, filtration coefficient. }\end{array}$ \\
\hline Composting & $\begin{array}{l}\text { Fish pond sediment mixed with fallen le } \\
\text { addition of urea and inoculated with mic } \\
\text { Trichoderma spp. and Phanerochaete } c h\end{array}$ \\
\hline Vermicomposting & $\begin{array}{l}\text { Sludge from the recirculating aquacultur } \\
\text { and subjected to vermicomposting with }\end{array}$ \\
\hline Vermicomposting & $\begin{array}{l}\text { Sludge from closed recirculating system } \\
\text { cardboard subjected to vermicomposting }\end{array}$ \\
\hline Energy recovery & $\begin{array}{l}\text { Fish pond sediment as an addition to sey } \\
\text { municipal wastewater treatment plant. } \mathrm{T} \\
\text { subjected to combustion in a fluidized be } \\
\text { recovery system. }\end{array}$ \\
\hline Biofuels & $\begin{array}{l}\text { Fish farm sludge used as a source for bic } \\
\text { biogas). }\end{array}$ \\
\hline Growing medium & Fish pond sediment used as a culture me \\
\hline \multicolumn{2}{|c|}{$\begin{array}{l}\text { methods for managing fish pond sediment that would allow } \\
\text { for the recovery of nutrients and/or energy through bio- } \\
\text { conversion processes to obtain value added products for } \\
\text { agricultural use. } \\
\text { Future work should focus on analysing the potential of } \\
\text { fish pond sediment in terms of its composition and sani- } \\
\text { tary safety as well as determining the quantities of removed } \\
\text { fish pond sediments from aquaculture systems. This would } \\
\text { allow for further studies concerning the efficient biocon- } \\
\text { version of fish pond sediment into products for agricultural } \\
\text { use and the development of on-farm aquaculture systems } \\
\text { integrated with managed fish pond sediments and other } \\
\text { organic residues. }\end{array}$} \\
\hline
\end{tabular}

Conflict of interest: The Authors do not declare conflict of interest.

\section{REFERENCES}

Antychowicz J., Pękala A., and Kramer I., 2017. Causes of loss in carp breeding and carp treatment (in Polish). Życie Weterynaryjne, 92(3), 190-199.

Barszczewski J., Kaca E., and Wojda R., 2010. The environmental conditions and production results in organic and conventional system of carp breeding. J. Res. Appl. Agric. Eng., 55(3), 14-19.

Bosma R.H. and Verdegem M.C.J., 2011. Sustainable aquaculture in ponds: Principles, practices and limits. Livestock Sci., 139, 58-68. https://doi.org/10.1016/j.livsci.2011.03.017
References

Eymontt et al., 2017

Haque et al., 2016

Report 9/2010 Nofima, 2010

Maj and Koszelnik, 2016

Zhang and Sun, 2017

Kouba et al., 2018

Marsh et al., 2005

Report 9/2010 Nofima, 2010

Report 9/2010 Nofima, 2010

Report 9/2010 Nofima, 2010
Boyd C.E., Wood C.W., Chaney P.L., and Queiroz J.F., 2010. Role of aquaculture pond sediments in sequestration of annual global carbon emission. Environ. Pollution, 158, 2537-2540. https://doi.org/10.1016/j.envpol.2010.04.025

Boyd C.E. and Massaut L., 1999. Risk associated with the use of chemicals in pond aquaculture. Aquacultural Eng., 4, 113132. https://doi.org/10.1016/s0144-8609(99)00010-2

Chowdhury P., Viraraghavan T., and Srinivasan A., 2010. Biological treatment processes for fish processing wastewater - A review. Bioresource Technol., 101, 439.449. https://doi.org/10.1016/j.biortech.2009.08.065

Delgado C., Wada N., Rosegrant M.W., Meijer S., and Ahmed M., 2003. The future of fish: issues and trends to 2020. IFPRI Issue Brief 15. Washington, DC, USA. https://cgspace.cgiar.org/handle/10568/2039

Directive of the Ministery Council from June, 5th 2018 on the accpetance of "the Program for mitigation of water contamination with nitrates from agriculture and prevention from further contamination, 2018 (in Polish), http://prawo. sejm.gov.pl/isap.nsf/download.xsp/WDU20180001339/O/ D20181339.pdf (Accessed: 12.07.2018)

Eymontt A., Wierzbicki K., Brogowski Z., Burzyńska I., and Rossa L., 2017. A new technology for removal of bottom sediments from ditches located in fish farms and the application of bottom sediments in agriculture (in Polish). Komunikaty Rybackie, 2(157), 7-13.

EU Organic Aquaculture, 2017. European Market Observatory for Fisheries and Aquaculture Products (EUFOMA), http:// www.eumofa.eu/documents/20178/84590/Study+report_ organic+aquaculture.pdf 
FAO, 2016. The State of World Fisheries and Aquaculture 2016. Food and Agriculture Organization of the United Nations, Rome, Italy. http://www.fao.org/3/a-i5555e.pdf

Fish market and consumption in 2016, 2017 (in Polish), http://www.sprl.pl/userfiles/files/Krzysztof\%20Hryszko.pdf

Haque M.M., Belton B., Alam M.M., Ahmed A.G., and Alam M.R., 2016. Reuse of fish pond sediments as fertilizer for fodder grass production in Bangladesh: Potential for sustainable intensification and improved nutrition. Agric. Ecosys. Environ., 216, 226-236. https://doi.org/10.1016/j.agee.2015.10.004

Hossain M.A., Sarker A.K., Amin M.N., and Hossain M.M., 2016. Development of performance evaluation of sludge remover from intensive aquaculture. Aquaculture Eng., 74, 62-69. https://doi.org/10.1016/j.aquaeng.2016.06.001

Karak T., Bhattacharyya P., Kumar R.P., Das T., and Saha S.K., 2013. Evaluation of composts from agricultural wastes with fish pond sediments as bulking agent to improve compost quality. CLEAN - Soil, Air, Water, 41(7), 711723. https://doi.org/10.1002/clen.201200142

Kibria A.S.M. and Haque M.M., 2018. Potentials of integrated multi-trophic aquaculture (IMTA) in freshwater ponds in Bangladesh. Aquaculture Reports, 11, 8-16. https://doi.org/10.1016/j.aqrep.2018.05.004

Kokou F. and Fountoulaki E., 2018. Aquaculture waste production associated with antinutrient presence in common fish feed plant ingredients. Aquaculture, 495, 295-310. https://doi.org/10.1016/j.aquaculture.2018.06.003

Kouba A., Lunda R., Hlaváč D., Kuklina I., Hamáčková J., Randák T., Kozák P., Koubová A., and Buřič M., 2018. Vermicomposting of sludge from recirculating aquaculture system using Eiseniaandrei: Technological feasibility and quality assessment of end-products. J. Cleaner Production, 177, 665-673. https://doi.org/10.1016/j.jclepro.2017.12.216

Li H., Ling W., and Lin C., 2011. Fishpond sediment-borne DDTs and HCHs in the Pearl River Delta: Characteristics, environmental risk and fate following the use of the sediment as plant growth media. J. Hazardous Materials, 186(2-3), 1474-1480. https://doi.org/10.1016/j.jhazmat.2010.12.031

Ma Y., Sun L., Liu C., Yang X., Zhou W., Yang B., Schwenke G., and Liu D.L., 2018. A comparison of methane and nitrous emissions from inland mixed-fish and crab aquaculture ponds. Sci. Total Environ., 637-638, 517-523. https://doi.org/10.1016/j.scitotenv.2018.05.040

Maj K. and Koszelnik P., 2016. Methods for management of bottom sediments (in Polish). Czasopismo Inżynierii Lądowej, Środowiska i Architektury, 63, 157-169. https://doi.org/10.7862/rb.2016.118

Marsh L., Subler S., Mishra S., and Marini M., 2005. Suitability of aquaculture effluent solids mixed with cardboard as a feedstock for vermicomposting. Bioresour. Technol., 96, 413-418. https://doi.org/10.1016/j.biortech.2004.06.002

Milhazaes-Cunha H. and Otero A., 2017. Valorisation of aquaculture effluents with microalgae: The integrated multitrophic aquaculture concept. Algal Res., 24, 416-424. https://doi.org/10.1016/j.algal.2016.12.011

Mirzoyan N., Parnes S., Singer A., Tal Y., Sowers K., and Gross A., 2008. Quality of brackish aquaculture sludge and its suitability for anaerobic digestion and methane production in an upflow anaerobic sludge blanket (UASB) reactor. Aquaculture, 279, 35-41. https://doi.org/10.1016/j.aquaculture.2008.04.008

Mizanur R., Yakupitiyage A., and Ranamukhaarachchi S.L., 2004. Agricultural use of fishpond sediment for environmental amelioration. Thammasat Int. J. Sci. Technol., 9(4), $1-12$.

Muendo P.N., Verdegem M.C.J., Stoorvogel J.J., Milstein A., Gamal E., Duc P.M., and Verreth J.A.J., 2014. Sediment accumulation in fish ponds; its potential for agricultural use, Int. J. Fisheries Aquatic Studies, 1(5), 228-241.

Organic production of fish in the EU - under a new flag to the tables of the world, 2016 (in Polish).

http://www.sprl.pl/userfiles/files/pdf/organic.pdf

Parvathy K.G., Umesh P.A., and Bhaskaran Prasad K., 2017. Inter-seasonal variability of wind-waves and their attenuation characteristics by mangroves in a reversing wind system. Int. J. Climatol., 37, 5089-5106.

https://doi.org/10.1002/joc.5147

Prevention in pond breeding of fish, 2016 (in Polish). https:// docplayer.pl/5348067-Profilaktyka-ogolna-w-produkcjistawowej-lek-wet-maciej-dragan-klinika-weterynaryjnaorka-czechowice-dziedzice.html

Quant B., Czerwionka K., and Remiszewska-Skwarek A., 2006. Bottom sediments from salmon fish farms (in Polish). Przegląd Komunalny, 9, 73-75

Rahman M.M. and Yakupitiyage A., 2006. Use of fishpond sediment for sustainable aquaculture-agriculture farming. Int. J. Sustainable Develop. Planning, 2, 192-202.

https://doi.org/10.2495/sdp-v1-n2-192-202

Remiszewska-Skwarek A. and Quant B., 2008. Analysis of the potential for management of bottom sediments from salmon breeding in view to the current legislation on the application of municipal sewage sludge (in Polish). Inżynieria i Ochrona Środowiska, 11(3), 311-318.

https://doi.org/10.5604/01.3001.0012.7460

Report 9/2010 Nofima, 2010. Utilization of sludge from recirculation aquaculture systems.

https://www.nofima.no/filearchive/Rapport\%2009-2010.pdf

States of Oregon Department of Environmental Quality, 2017. Food Product Environmental Footprint Literature Summary: Land-Based Aquaculture. Center for Sustainable Systems, University of Michigan, USA.

The Code of Best Practices for Fish Breeding, 2015 (in Polish). http://pankarprybacy.pl/Kodeks_dpr.pdf

Tran N., Rodriguez U.P., Chan C.Y., Phillips M.J., Mohan C.V., Henriksson P.J.G., Koeshendrajana S., Suri S., and Hall S., 2017. Indonesian aquaculture futures: An analysis of fish supply and demand in Indonesia to 2030 and role of aquaculture using the AsiaFish model. Marine Policy, 79, 25-32. https://doi.org/10.1016/j.marpol.2017.02.002

Van Rijn J., 2013. Waste treatment in recirculating aquaculture systems. Aquacultural Eng., 53, 49-56.

https://doi.org/10.1016/j.aquaeng.2012.11.010

Zhang L. and Sun X., 2017. Addition of fish pond sediment and rock phosphate enhances the composting of green waste. Bioresource Technol., 233, 116-126. https://doi.org/10.1016/j.biortech.2017.02.073 